\title{
Analysis of the distribution of the raw material base for biogas production in communes of the małopolskie voivodship
}

\author{
Jakub Sikora $^{1, *}$ and Edyta Leśniak ${ }^{1}$ \\ ${ }^{1}$ University of Agriculture in Krakow, Faculty of Production and Power Engineering, ul. Balicka 116B, 30-149 Krakow, Poland
}

\begin{abstract}
The purpose of the work was to determine the electricity production potential of the available fermentation masses of selected organic fractions in the Małopolskie voivodship, as aggregated at the commune level. The determined potential of biomass production for energy purposes was presented in the form of a spatial distribution, based on data obtained from the queries of the Central Statistical Office. The purpose of the correlation was to facilitate the analysis of the problem of creating agricultural biogas plants in the discussed area. The scope of the study included all communes in the Małopolskie voivodship, as well as public statistics on the sown acreage for cereals, maize, the number of population, the population of pigs and cattle, as well as municipal solid waste. The tool used in the study was the Biogas Calculator of the Masovian Energy Agency and the software for creating spatial databases, ArcView 10.2.1
\end{abstract}

\section{Introduction}

In addition to its advantages, the development of civilization, unfortunately, also has disadvantages. One of the issues that involve both economics and ecology is waste management (Ministry of Agriculture and Rural Development, MRIRW). This is an up-to-date topic and it will always be one, because it is associated with everyday activities of every human being. All of us are waste producers, and unfortunately, the scale grows from day to day. The share of the organic fraction is the main criterion for the division of the generated waste [5].

Waste management should consist in reducing the amount of waste, then making maximum use of that, which has already been created, and only then, finally, storage. Unfortunately, it is different in Poland. According to data from the National Waste Management Plan of 2013 , over $63 \%$ of the generated waste went to landfills. However, there are methods by which waste can find a positive application [3].

The condition of rural areas is affected mostly faeces and urine, i.e. animal faeces, municipal sewage sludge, as well as harmful compounds found in them and their entry into the atmosphere. Therefore, the search for methods allowing the use of these components was launched [7].

One of such methods is the biological processing of the above mentioned masses. An example of this is the anaerobic digestion of organic matter. In addition to the fact that they use different types of substrates depending on the mass available, agricultural biogas plants can also be part of the energy island. This means that they not only produce energy, but can be supplied with a surplus created in another source [4]. In Germany and Denmark, agricultural biogas plants have been operating for 10 - 15 years, and their number is constantly growing [1]. In Poland, the first agricultural biogas plant was built in 2005 , and it is still in operation. In 2015, the number of installations included in the Agricultural Biogas Plant Register of the Agricultural Market Agency in Poland was over 50. However, biogas installations in Poland still raise controversy among the public $[9,11]$.

The input mass for a biogas plant can come from a variety of sources: agriculture, animal husbandry, and industrial or municipal waste. A stable substrate, available for a long time, is crucial in the process of biogas production, which is created during methane fermentation. The fermentation can be interrupted at any time, hence the need to control and properly transmit information regarding, among others, the distribution of the raw material base using information systems.

Against the backdrop of alternative information systems, the SIP spatial information systems are distinguished by the inclusion of spatial information. The information includes both natural and artificial stable objects and social, economic and natural phenomena. Another attribute characteristic for the SIP is the capability of cartographic presentation and analysis in terms of the real world, in relation to the modelled system. Such analysis includes making measurements, determining the proximity of objects or finding points with specific parameters (http://infgeo.strefa.pl).

Local authorities are responsible for shaping the environment and its protection. Improvements implemented in communes involve the use of SIP on various levels, which depend on the nature of the commune and, above all, its size. Communes with larger areas, especially municipalities, use GIS to improve the so-called city management process $[11,12]$. In addition to basic information about building plots, objects or

*Corresponding author: Jakub.Sikora@ur.krakow.pl 
utilities, the spatial development plan plays a significant role $[13,14]$.

The purpose of the work was to determine the electricity production potential of the available fermentation masses of selected organic fractions in the Małopolskie voivodship, as aggregated at the commune level. The determined potential of biomass production for energy purposes was presented in the form of a spatial distribution, based on data obtained from the Central Statistical Office's queries. The purpose of the correlation was to facilitate the analysis of the problem of creating agricultural biogas plants in the discussed area.

\section{Methodology and subject of study}

Data for analysis were obtained from the Local Data Bank of the Statistical Office in Krakow. Data on the sown area and livestock population by type of farm at the municipal level in the Małopolskie voivodship, as well as the population of individual communes, was obtained from the Agricultural Census (PSR) as of Dec 31, 2014. The data were divided into groups:

- cereal mass,

- organic mass,

- animal production waste,

- municipal waste.

The sorted data were collected in the MS Excel spreadsheet, where further calculation activities were performed. Then the mean annual mass of yields in $\mathrm{Mg}$ was calculated for individual subgroups. In the case of animal production, the focus was on the annual amount of manure produced. Data referring to the population was used to determine the amount of municipal organic waste in $\mathrm{Mg}$ per year.

The obtained data were used to calculate the annual methane yield; the tool used was the Biogas Calculator of the Masovian Energy Agency. The calculator is used to estimate the volume of biogas production, as well as the amount of investment in biogas investments, and its economics.

$\mathrm{CH}_{4}$ yieldfrom vegetable substrates is calculated based on the amount of their yields, animal production based on the amount of manure produced, and human production - based on the amount of organic municipal waste production, as shown by the following equation:

$$
U_{C H 4}=P_{J} * W\left[m^{3} *(\text { year })^{-1}\right]
$$

where:

$\mathrm{U}_{\mathrm{CH} 4}$ - annual methane yield from individual fractions $\left[\mathrm{m}^{3} *(\text { year })^{-1}\right]$,

$\mathrm{P}_{\mathrm{J}^{-}}$annual production unit of $\mathrm{CH}_{4}$ (data from the Biogas Calculator) $\left[\mathrm{m}^{3} *(\text { year } * \mathrm{Mg})^{-1}\right]$,

$\mathrm{W}$ - annual amount of input from individual fractions $\left(\mathrm{M}_{\mathrm{P}}\right.$, or $\mathrm{I}_{\mathrm{O}}$, or $\left.\mathrm{I}_{\mathrm{OK}}\right)[\mathrm{Mg}]$,

The assumed biomass potential is presented in Table 1.

Table 1. Methane production from selected organic fractions

\begin{tabular}{|c|c|c|}
\hline Type of input & $\begin{array}{c}\text { Annual substrate input [Mg } \\
\left.\mathbf{y e a r}^{-1}\right]\end{array}$ & $\begin{array}{c}\text { Annual methane production } \\
{\left[\mathbf{m}^{\mathbf{3}} \mathbf{y e a r}^{-1} \mathbf{]}\right.}\end{array}$ \\
\hline \multicolumn{2}{|c|}{ ENERGY CROPS AND AGRICULTURAL WASTE } \\
\hline Wheat - silage & 1 & 111.52 \\
\hline Maize - silage & 1 & 94.11 \\
\hline Rape - silage & 1 & 167.55 \\
\hline Whole potatoes & 1 & 96.19 \\
\hline Onion & 1 & 43.87 \\
\hline Cattle manure & ANIMAL HUSBANDRY WASTE & 45.07 \\
\hline Pig manure & 1 & 43.30 \\
\hline \multicolumn{3}{|c|}{ MUNICIPAL WASTE } \\
\hline
\end{tabular}

The next step was to calculate the nominal power of the generator in the cogeneration system. It was determined from the equation:

$$
\mathrm{E}_{\mathrm{el}}=\frac{\mathrm{E}_{\text {tot }} \mathrm{\eta}_{\mathrm{el}}}{\mathrm{T}_{\mathrm{p}}}[\mathrm{kW}]
$$

where:

$\mathrm{E}_{\text {tot }}-$ total thermal energy contained in fuel [ $\mathrm{kWh}$,

$\eta_{\mathrm{el}}$ - efficiency of electricity conversion [\%],

$\mathrm{T}_{\mathrm{p}}$ - biogas introduction time $[\mathrm{h}]$.

$$
\mathrm{E}_{\text {tot }}=\mathrm{V}_{\text {sub }} * \mathrm{Q}_{\text {bio }}[\mathrm{kWh}]
$$

where:

$\mathrm{V}_{\text {sub }}$ - flow of biogas volume $\left[\mathrm{m}^{3} *(\mathrm{~d})^{-1}\right]$,
$\mathrm{Q}_{\text {bio }}$ - calorific value of biogas $\left[\mathrm{kWh} *\left(\mathrm{~m}^{3}\right)^{-1}\right][5]$.

In order to calculate the total heat energy contained in the fuel, the annual methane yield was divided into 365 days, which resulted in information about the daily yield.

$$
V_{s w b}=\frac{U_{C H 4}}{365}\left[m^{3} *(d)^{-1}\right]
$$

Then, the calorific value of biogas equal to $\mathrm{Q}_{\mathrm{bio}}=6$ $\mathrm{kWh} *\left(\mathrm{~m}^{3}\right)^{-1}$ was assumed. The energy thus obtained was multiplied by the efficiency of electricity conversion of $\eta_{\mathrm{el}}=39 \%$. Finally, the energy obtained was divided over time (24 hours), which showed the daily power of the system in MW. These calculations were conducted in relation to each of the subgroups. 
Next, data on the methane yield of individual groups and the calculated power of the generator in the cogeneration system were collected in a MS Office Excel worksheet, and columns of data sums from the analyzed subgroups in both categories were added. The next step was to generate spatial databases in the form of maps.

The area of the Małopolskie voivodship was adopted as the subject of the research. The area of agricultural land in Małopolskie was $4.4 \%$ of the national total. On the other hand, sowing in Małopolskie accounted for about $3.0 \%$ of the national total. The average area of ecological farms in Małopolskie in 2011 was 10 ha. Along with the increase in the area of farms, the proportion of fodder plants increased in relation to other crops $[2,13]$. Figure 1a shows the structure of land use in Małopolskie in 2012.

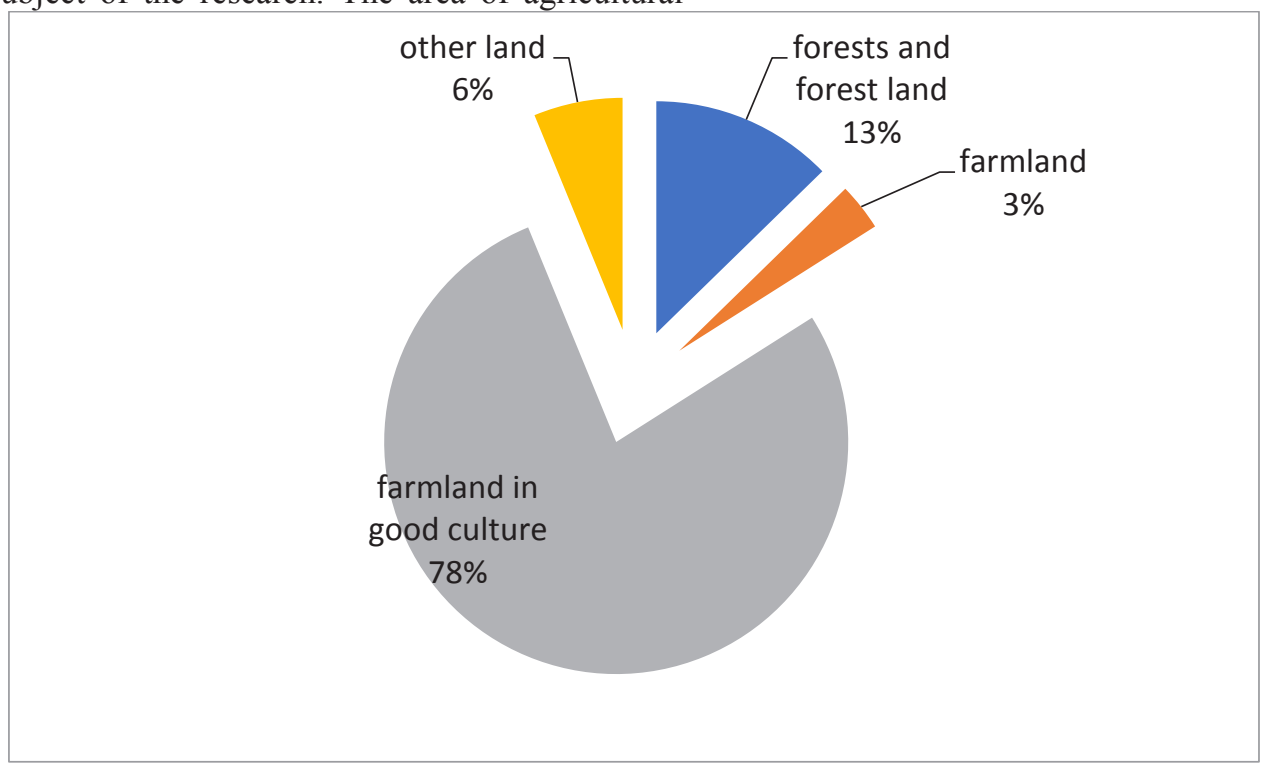

Figure 1 a. Structure of land use in agricultural enterprises in 2012 in Małopolskie voivodship.

The above figure demonstrates that the largest share was occupied by good quality arable land, which constituted as much as $78 \%$. Forests and forest land accounted for $13 \%$. The least acreage was occupied by agricultural land, the soil condition of which was unsatisfactory; it accounted for 3\%. The region of Małopolskie voivodship is intensively exploited agriculturally, with the exception of the higher parts of the Carpathians. Agricultural land covers about $58 \%$ of the area, of which arable land constitutes approx.. $75 \%$ of the area of agricultural land on average.

A spatial database was developed and generated for this area. The Figure below (Figure 1b) demonstrates the study area.
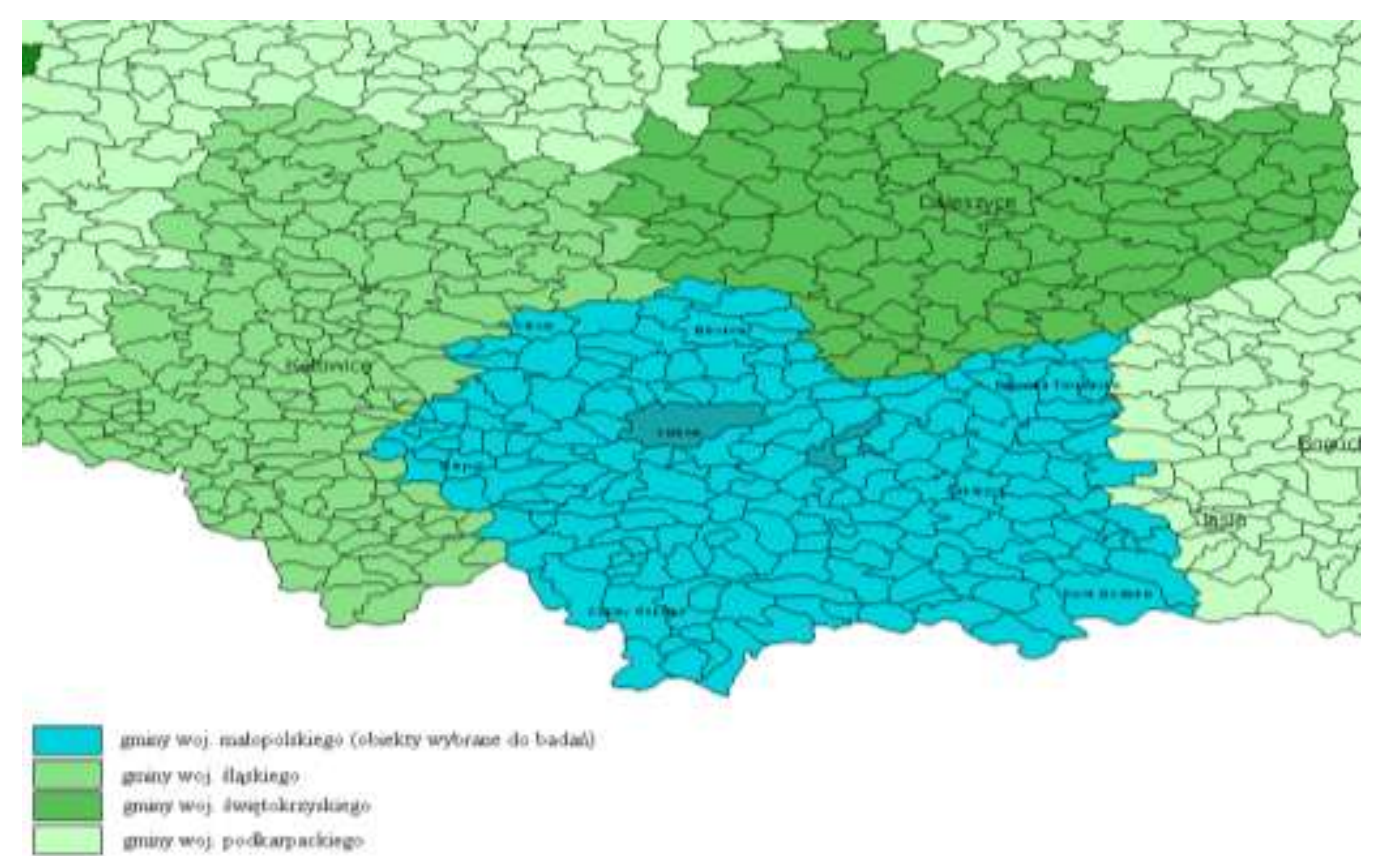

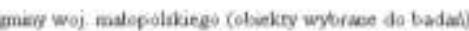

grany woy tiakiegs

emaing woj iveqtakragicange

Eury woj pedcamackiego

Figure 1b. The study area. 


\section{Findings}

The summary data on the nominal value of Eel shows that in the Małopolskie voivodeship there may be the following maximum number of biogas plants for each group:

- microbiological biogas plants 2

- small biogas plants 6

- large biogas plants 175
Maps were generated based on the obtained data and developed analyses and calculations.

The following drawings (Figure 2 - Figure 7) present the spatial development of the data in question. These are data on the biomethane production potential of individual substrates at the commune level and the electricity generating potential of the obtained biomethane.

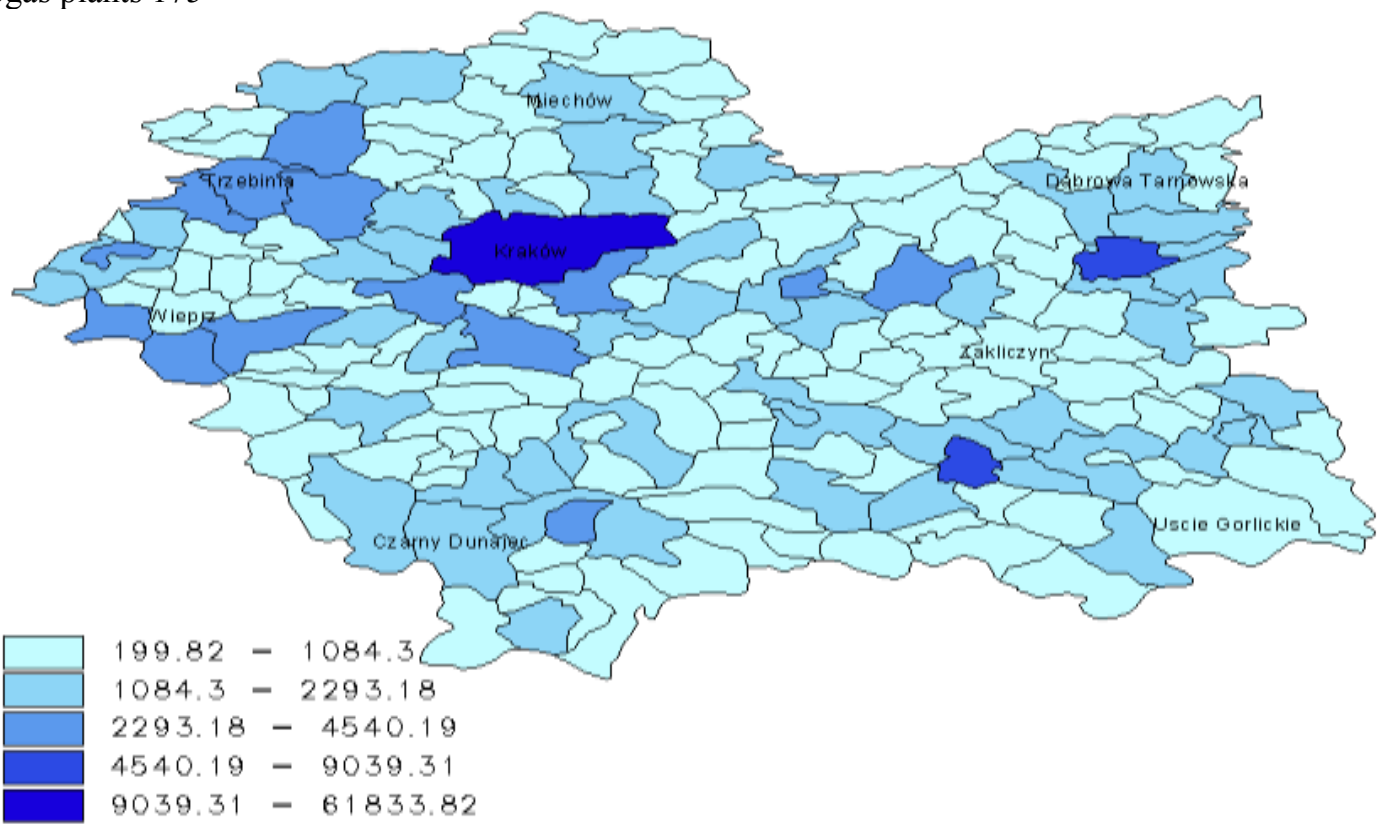

Figure 2. Potential of biomethane production of the organic fraction of municipal waste at the commune level of the Małopolskie voivodship.

The volume of municipal waste production is closely related to the number of inhabitants of a given commune, so the potential of methane production will grow similarly with the increase in the population of the region. Municipalities with the largest $\mathrm{CH}_{4}$ production potential in the Małopolskie voivodship are: the municipality of Krakow with a daily quantity of
$6,183,3,82 \mathrm{~m}^{3}$ of biomethane, the municipality of Tarnow, with over $9,000 \mathrm{~m}^{3}$ per day, and Nowy Sacz with $6805 \mathrm{~m}^{3}$ per day. The lower range of the scale is occupied by the municipalities of Racławice and Bolesław, with a daily methane yield of approx. $200 \mathrm{~m}^{3}$. The average value in this category is $1505 \mathrm{~m}^{3} \mathrm{CH}_{4}$.

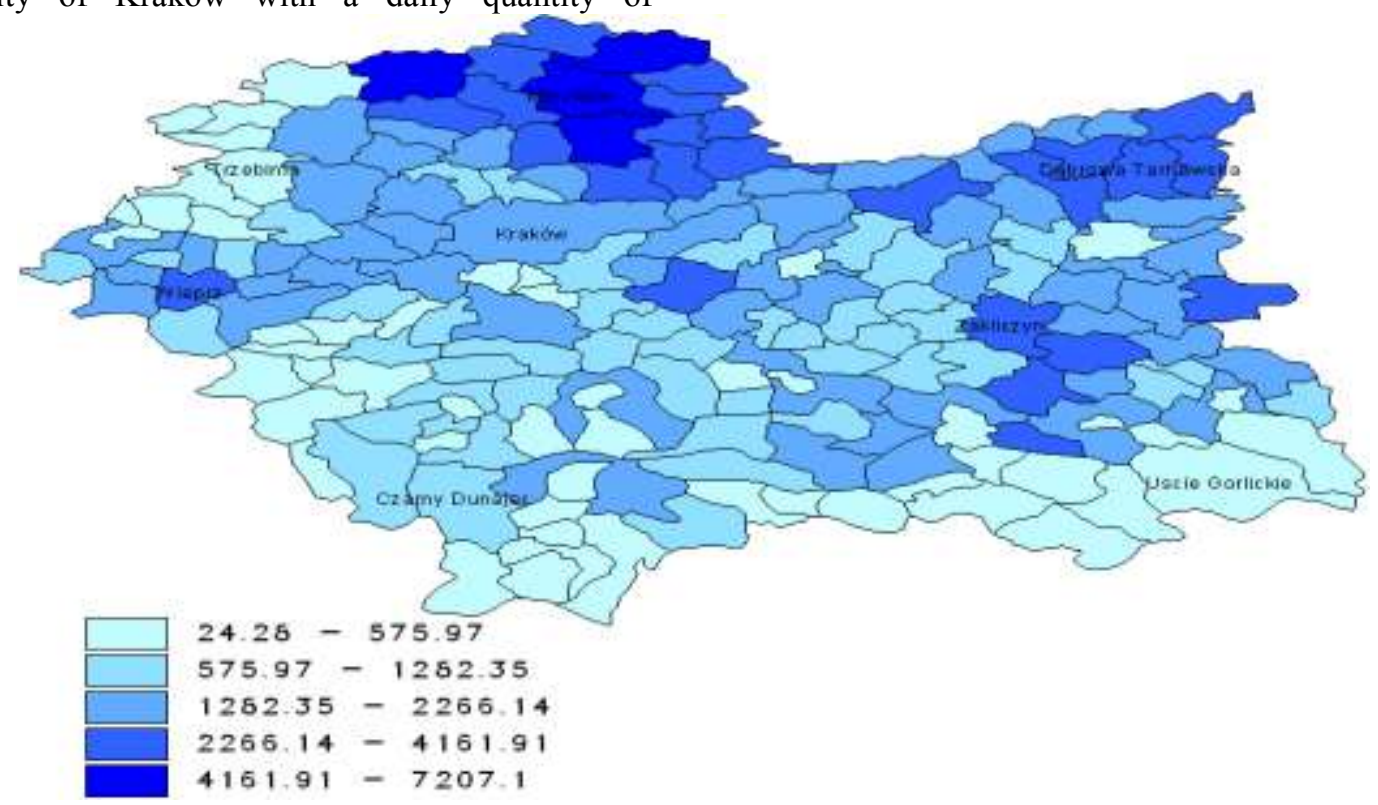

Figure 3. Potential of biomethane production of the production waste mass at the commune level of the Małopolskie voivodship. 
The potential of biomethane production from grain production masses in the communes of Małopolskie voivodship is growing towards the northern part of the area. The minimum value is $24.27 \mathrm{~m}^{3}$ for the municipality of Szczawnica, then Bukowno, Zakopane and Sucha Beskidzka, i.e. mountain areas. The maximum value is over $7200 \mathrm{~m}^{3}$. Such methane yields from cereals are possible in the municipality of Miechów.

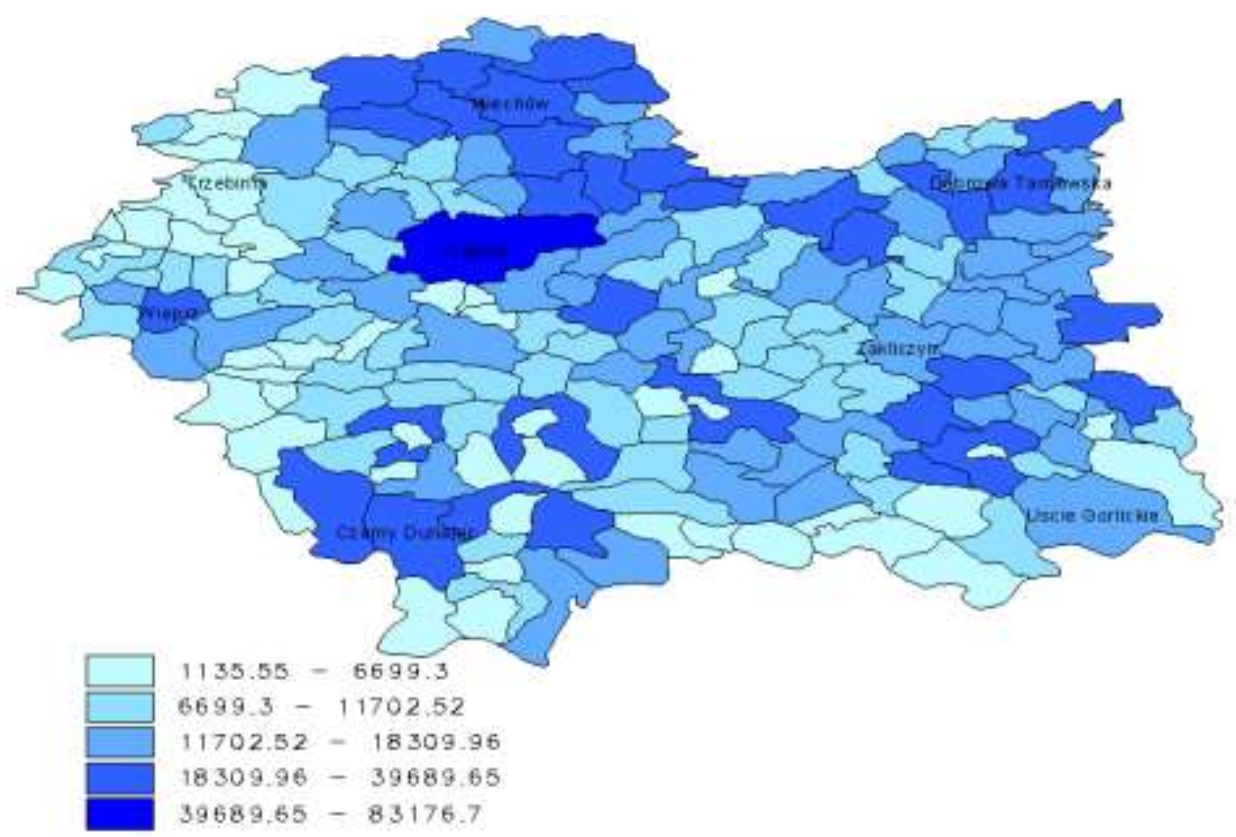

Figure 4. Potential of biomethane production from all studied masses at the commune level of the Małopolskie voivodship.

The potential of biomethane production from all studied masses at the commune level of the Małopolskie voivodship is diversified. A tendency for higher potential to accumulate in the north-western part of the voivodship is noticeable. Municipalities with the highest biogas production potential of the studied fractions, at $100 \%$ biogas development, are: the municipality of Krakow, with a daily yield of $83176.7 \mathrm{~m}^{3}$, then the municipality of Miechów, with over two times lesser potential, and further the communes of Proszowice, Czarny Dunajec and Żabno. The lowest potential in terms of $\mathrm{CH}_{4}$ yield ischaracteristic of the communes Bukowno $\left(1135.5 \mathrm{~m}^{3}\right)$, Sucha Beskidzka, Szczawnica, Rytro and Jordanów.

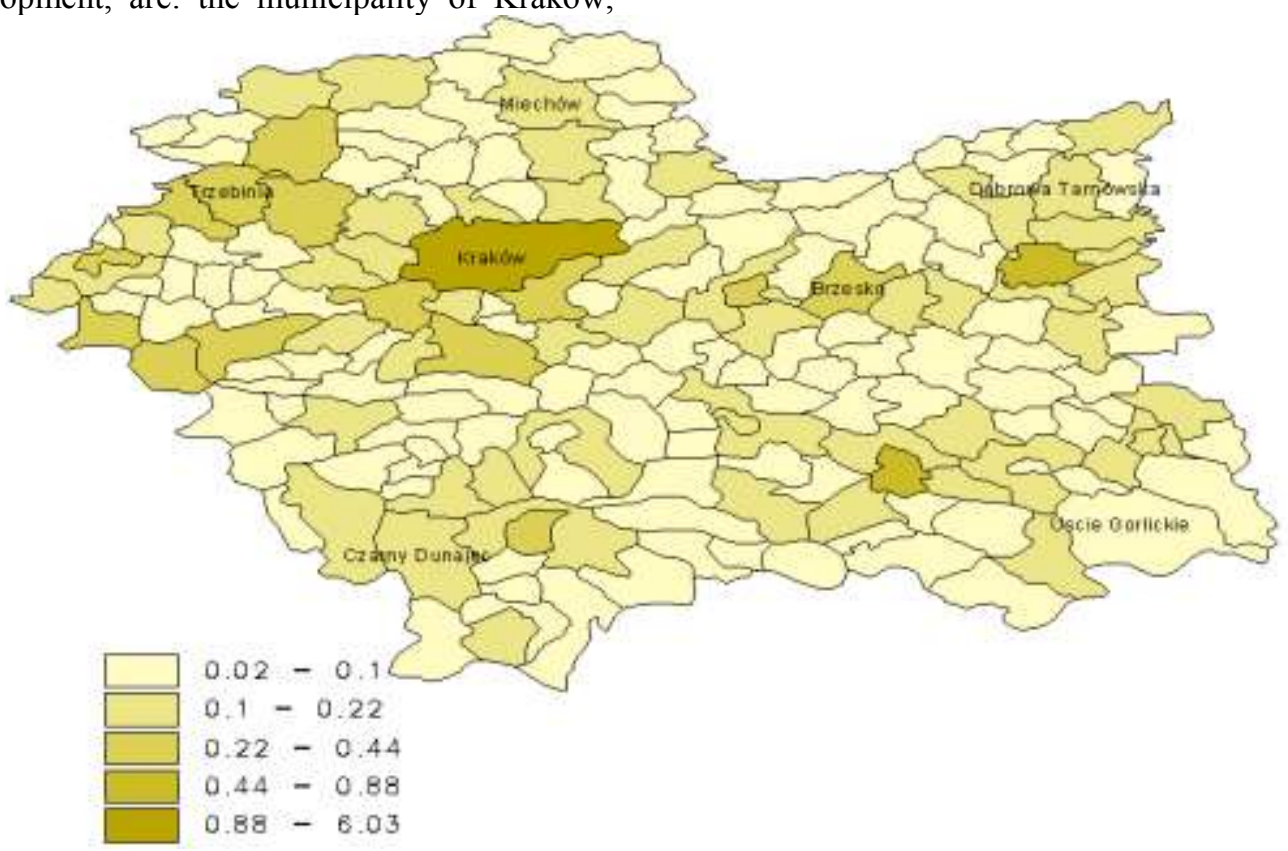

Figure 5. Potential for generating electricity from biomethane obtained from the organic fraction of municipal waste.

In the Małopolskie voivodship, the potential for generating electricity from biomethane produced from municipal waste ranges from 0.019 to $6.028 \mathrm{MW}$, and as such, it is differentiated. Its mean value is $0.146 \mathrm{MW}$. The maximum result is assigned to the municipality of Krakow, which is related to the population of the city 
and its area. Second largest result, only $0.881 \mathrm{MW}$, is assigned to the municipalities of Tarnow and then Nowy Sacz. Thus, a direct corellation can be observed between the number of residents and the amount of waste, and at the same time the higher energy potential. The lower range of $0.02 \mathrm{MW}$ is taken by the communes: Racławice, Bolesław, Radziemice, Gremboszów and Mędrzechów.

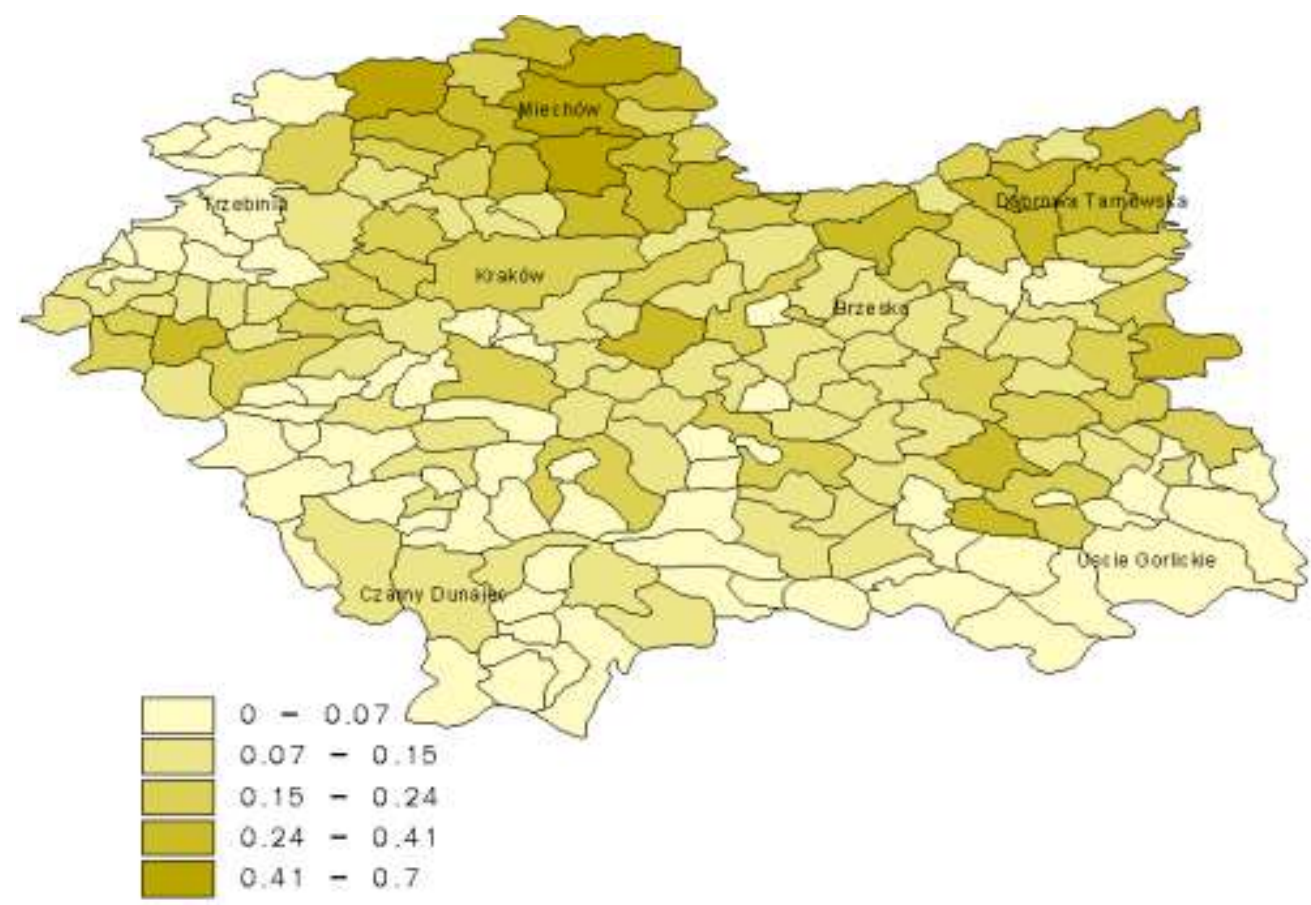

Figure 6. Potential for generating electricity from biomethane obtained from cereal masses.

The energy potential of cereal masses increases towards the north of the voivodship. The spatial distribution of individual plants also demonstrates the soil and climatic conditions of the studied area. It is clear, therefore, that mountain areas are not suitable for growing cereals. The amount of energy possible to obtain from cereals (assuming 100\% consumption for biogas purposes) ranges from 0.0023 to $0.702 \mathrm{MW}$. The average value was $0,129 \mathrm{MW}$. The values of the lower range are assigned to the communes of Szczawnica, Bukowno, and Zakopane, i.e. mountain communes, while the maximum value of energy potential of biomethane obtained from cereal masses is assigned to the municipality of Miechów in the north of the voivodship.

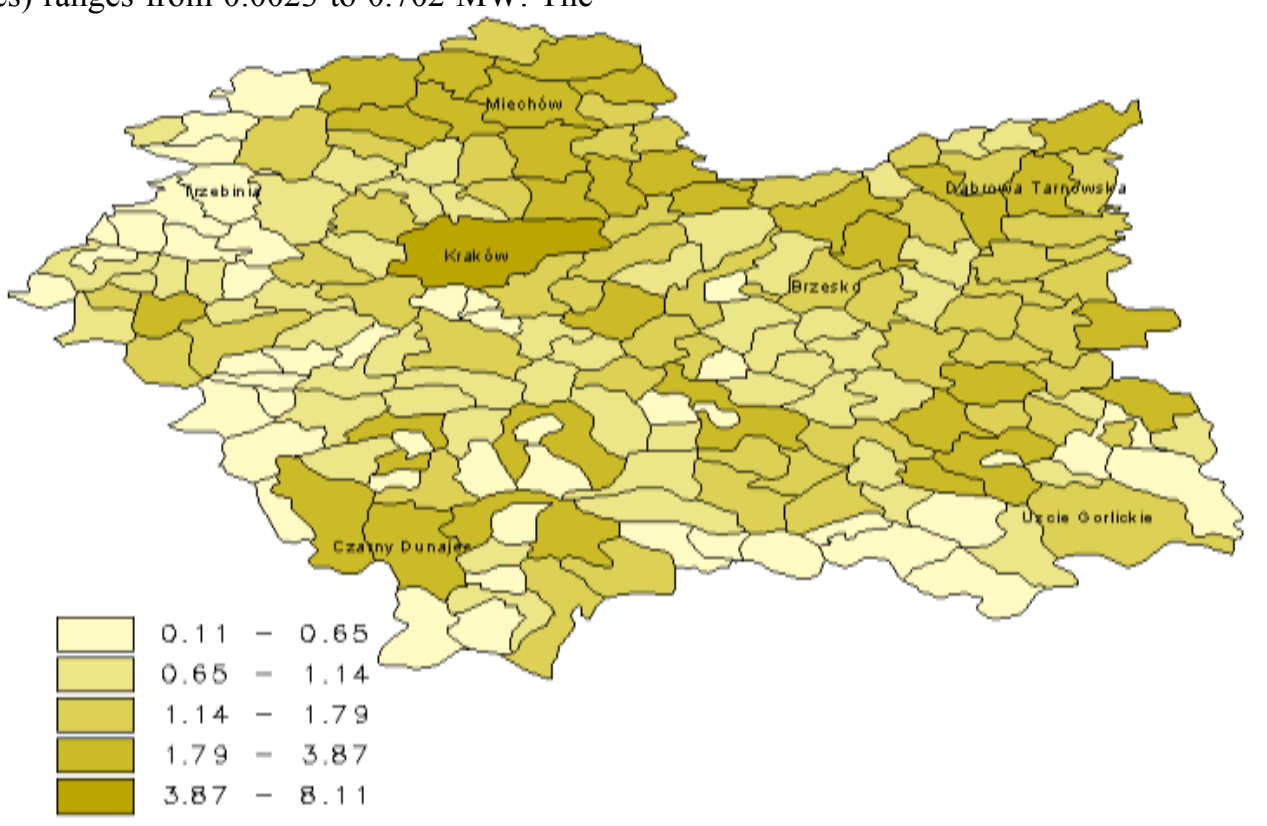

Figure 7. Potential for generating electricity from biomethane obtained from all studied fractions.

When discussing the spatial distribution of all studied fractions, it can be seen that the potential for the generation of electricity from biomethane obtained from all studied fractions in the Małopolskie voivodship is 
diversified. It ranges from $0.11 \mathrm{MW}$ in the Bukowno commune and 0.13 MW in Sucha Beskidzka to 8,109 MW in Krakow. This is impacted by the amount of municipal waste. The municipality of Krakow with 3.8 MW, is followed by the municipality of Miechow and further by the communes of Proszowice, Czarny Dunajec and Żabno. The average energy potential in the Małopolskie voivodship is 1,216 MW.

\section{Conclusion}

Implementation of renewable energy sources, including agricultural biogas plants, is one of the ways to protect the environment as well as to save the depleted resources of fossil fuels. The introduction of biogas plants aims at the management of agricultural waste. The waste generated during methanogenesis can be used as a fertilizer rich in organic compounds, or be reused in the next methanogenic cycle. Małopolskie voivodship has the potential to build biogas installations.

In the case of the nominal power of the generator in the cogeneration system, the situation is similar to methane yield. The nominal power of power generators ranges from 0.11 MW to as much as 8,109 MW in Krakow. In Krakow, this power is overestimated by the organic fraction of municipal waste. The best agricultural commune, with the potential of $3.8 \mathrm{MW}$ is the municipality of Miechów. In the medium range were the following communes: Proszowice, Czarny Dunajec and Żabno. The studies included $100 \%$ utilization of the tested fractions for biogas purposes.

\section{References}

1. Appel F., Ostetmeyer - Wiethaup A., Utilities Policy 41, (2016)

2. Czarnecka L. et al., Raport o stanie środowiska w województwie małopolskim w 2012 roku Gospodarowanie odpadami, Voivodeship
Inspectorate of Environmental Protection (WIOŚ), (2013)

3. Dec Ł., Sprawozdanie z realizacji Krajowego planu gospodarki odpadami za okres od 1 stycznia $2011 \mathrm{r}$. do 31 grudnia 2013 r., (2016)

4. Niemiec M, Sikora J., Szeląg-Sikora A., Kuboń M., Olech E., Marczuk A. Przemysł chemiczny 96(3),685-688 (2017)

5. Sikora J., Mruk B., nr III/2/2016, POLISH ACADEMY OF SCIENCES in Krakow, p. 907-917 the Committee for Rural Technical Infrastructure, (2016)

6. Szeląg-Sikora A., Cupiał M., Niemiec M. Agriculture and Agricultural Science Procedia. 7, 94-98, (2015)

7. Mazovian Engergy Agency (MAE), the Biogas Calculator http://www.mae.com.pl

8. Ministry of Agriculture and Rural Development (MRIRW), Agricultural Biogas Plants in Poland. http://www.minrol.gov.pl/

9. SIP, SIT, GIS, Geomatyka, http://infgeo.strefa.pl/K14/sip_gis_geomatyka.pdf

10. Tytko R., Urzadzenia $i$ systemy energetyki odnawialnej, (2013)

11. Wróbel, M., Frączek, J., Francik, S., Ślipek, Z., \& Mudryk. 12th International Scientific Conference on Engineering for Rural Development Proceedings ,12, 653-657, (2013).

12. Mudryk, K., Frączek, J., Ślipek, Z., Francik, S., \& Wróbel, M. 12th International Scientific Conference on Engineering for Rural Development Proceedings ,12, 658-662, (2013).

11. Slovak Association Publishing House, Krakow

12. Valenti F., Porto S. at al, 2017, Use of citrus pulp for biogas production: A GIS analysis of citrus-growing areas and processing industries in South Italy, Land Use Policy 66

13. Kuboń M., Krasnodębski A. Agricultural Economis, 56, 397-402 (2010) 